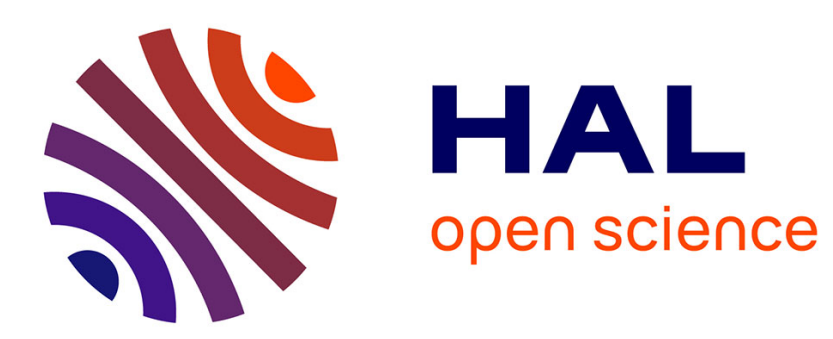

\title{
AFM combined to ATR-FTIR reveals Candida cell wall changes under caspofungin treatment
}

Fabienne Quilès, Isabelle Accoceberry, Célia Couzigou, Gregory Francius, Thierry Noël, Sofiane El-Kirat-Chatel

\section{- To cite this version:}

Fabienne Quilès, Isabelle Accoceberry, Célia Couzigou, Gregory Francius, Thierry Noël, et al.. AFM combined to ATR-FTIR reveals Candida cell wall changes under caspofungin treatment. Nanoscale, 2017, 9 (36), pp.13731-13738. 10.1039/c7nr02170d . hal-02046575

\section{HAL Id: hal-02046575 \\ https://hal.univ-lorraine.fr/hal-02046575}

Submitted on 21 Apr 2021

HAL is a multi-disciplinary open access archive for the deposit and dissemination of scientific research documents, whether they are published or not. The documents may come from teaching and research institutions in France or abroad, or from public or private research centers.
L'archive ouverte pluridisciplinaire HAL, est destinée au dépôt et à la diffusion de documents scientifiques de niveau recherche, publiés ou non, émanant des établissements d'enseignement et de recherche français ou étrangers, des laboratoires publics ou privés. 


\title{
AFM combined to ATR-FTIR reveals Candida cell wall changes under
}

\section{caspofungin treatment}

\author{
Fabienne Quilès ${ }^{1,2}$, Isabelle Accoceberry ${ }^{3}$, Célia Couzigou ${ }^{3}$, Grégory Francius ${ }^{1,2}$, \\ Thierry Noël ${ }^{3}$, and Sofiane El-Kirat-Chatel ${ }^{1,2 *}$
}

${ }^{1}$ CNRS, Laboratoire de Chimie Physique et Microbiologie pour l'Environnement, LCPME, UMR 7564, Villers-lès-Nancy, F-54600, France.

${ }^{2}$ Université de Lorraine, Laboratoire de Chimie Physique et Microbiologie pour I'Environnement, LCPME, UMR 7564, Villers-lès-Nancy, F-54600, France.

${ }^{3}$ Université de Bordeaux, CNRS, UMR 5234, Microbiologie Fondamentale et Pathogénicité, Bordeaux, France

* Corresponding author:

Sofiane El-Kirat-Chatel: elkirat1@univ-lorraine.fr 


\section{TABLE OF CONTENTS ENTRY}

AFM was combined to vibrational spectroscopy to decipher morphological, mechanical and biochemical changes induced by caspofungin treatment on Candida.

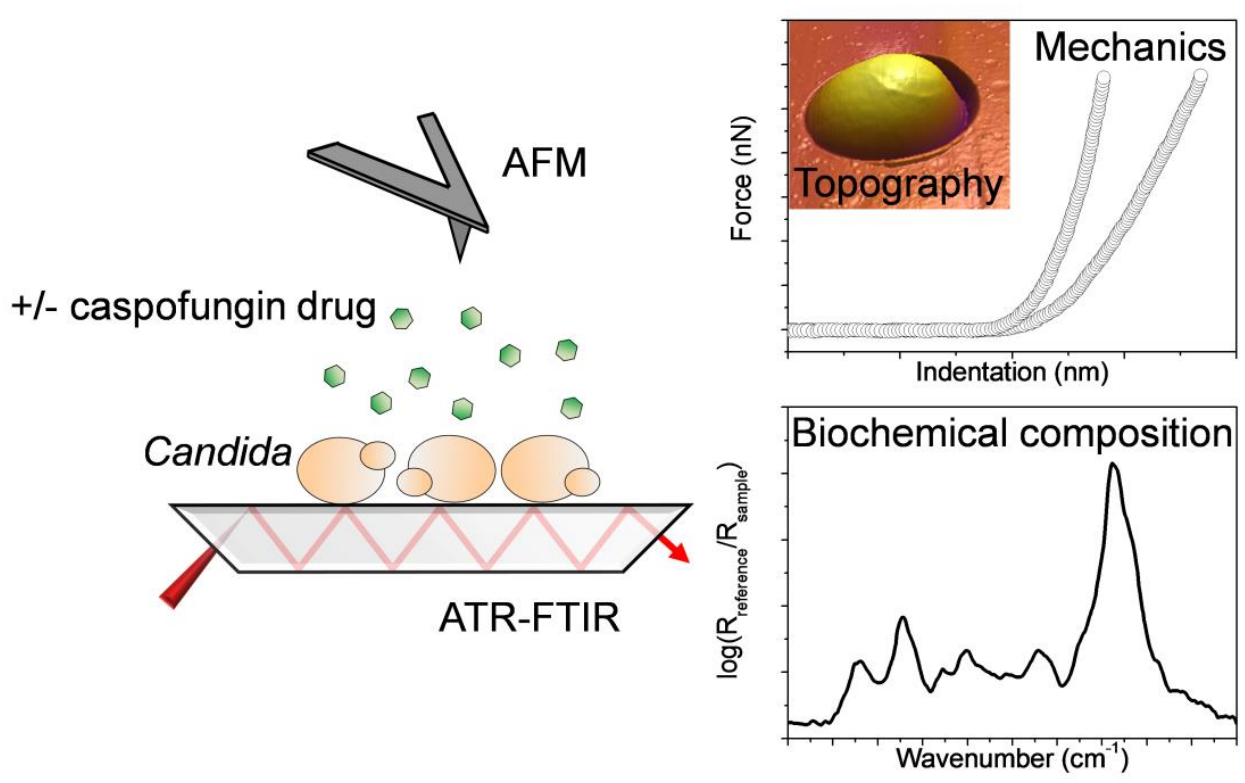




\section{ABSTRACT}

Fungal pathogens from Candida genus are responsible for severe life-threatening infections and the antifungal arsenal is still limited. Caspofungin, an antifungal drug used for human therapy, acts as a blocking agent of the cell wall synthesis by inhibiting of the $\beta-1,3-$ glucan-synthase encoded by FKS genes. Despite its efficiency, the number of genetic mutants that are resistant to caspofungin is increasing. An important challenge to improve antifungal therapy is to understand cellular phenomenon that are associated with drug resistance. Here we used atomic force microscopy (AFM) combined to Fourier transformed infrared spectroscopy in attenuated total reflection mode (ATR-FTIR) to decipher the effect of low and high drug concentration on the morphology, mechanics and cell wall composition of two Candida strains, one susceptible and one resistant to caspofungin. Our results confirm that caspofungin induces a dramatic cell wall remodelling via activation of stress responses, even at high drug concentration. Additionally, we highlighted unexpected changes related to drug resistance, suggesting that caspofungin resistance associated with FKS gene mutations comes from a combination of effects: i) an overall remodelling of yeast cell wall composition; and ii) cell wall stiffening through chitin synthesis. This work demonstrates that AFM combined to ATR-FTIR is a valuable approach to understand at the molecular scale the biological mechanisms associated with drug resistance. 


\section{Introduction}

Candidiasis represents an important public health problem caused by yeast species from Candida genus. Infections in immunocompromised patients are associated with high mortality rates ${ }^{1}$ and the antifungal drug repertoire for clinical therapy is still limited. ${ }^{2}$ Four groups of antifungals are traditionally used to treat deep human fungal infections: polyenes that bind to ergosterol in the plasma membrane and disturb cellular permeability; azoles that block ergosterol synthesis; fluorinated pyrimidines that interfere with protein synthesis and DNA replication; and echinocandins that block the $\beta$-1,3-glucan-synthase encoded by FKS genes and that are involved in cell wall biosynthesis. ${ }^{2-4}$ Echinocandins constitute a class of antifungals available since early 2000's and are recommended for effective treatment of invasive candidiasis. ${ }^{5,6}$ By blocking the synthesis of $\beta-1,3-D-g l u c a n s$, an essential homopolysaccharide of Candida cell wall, ${ }^{7,8}$ echinocandin such as caspofungin disturbs cell morphology ${ }^{9-12}$ and cell wall integrity and ultimately leads to cell death. ${ }^{6}$ However, there is an increased frequency of resistances acquired during therapy. ${ }^{13}$ In C. albicans, exposure to subinhibitory concentrations of caspofungin activates stress response pathways that result in adhesins-associated cellular aggregation to decrease drug diffusion and lower the effect of caspofungin on cells. ${ }^{11,14-17}$ To compensate the mechanical failure caused by the decrease in $\beta$-1,3-D-glucans, some cells produce larger amount of chitin, a major polysaccharide for cell wall strength. ${ }^{16,18,19}$ Although few reports describe the effect of caspofungin on the ultrastructure of yeast cell wall at high resolution, ${ }^{9-12}$ the changes occurring when cells are exposed to high antifungal concentrations are still poorly investigated. In the same line, whereas some genetic mutations of FKS genes are directly linked to caspofungin resistance, their consequences on the cell wall composition and properties during antifungal treatment have been poorly studied. Atomic force microscopy (AFM) has proven its versatility to study 
microbial cells morphology and mechanics under physiological conditions. ${ }^{20-22}$ AFM tips have been successfully used as imaging tools, molecular probes or nanoindentors to decipher ultrastructural changes in relation to antimicrobial drug effects. ${ }^{11,12,23}$ In complement to this local analysis at the nanoscale, the biochemical composition of the yeast can be investigated by infrared spectroscopy, a technique in which the spectra exhibits the weighted superposition of the infrared fingerprints of the biomolecules. ${ }^{24,25}$ As the IR evanescent wave penetrates less than $1.5 \mu \mathrm{m}$ beyond the crystal in the attenuated total reflection mode (ATRFTIR), this weighting depends not only on the chemical compound concentration but also on the distance between molecules and the crystal surface. Therefore, this non-destructive technique provides a highly specific biochemical "fingerprint" of yeast cell wall. This approach has been applied to characterize cell modifications related to various external stimuli. ${ }^{25,26}$ Here, we combined AFM and ATR-FTIR to compare morphological, mechanical and biochemical properties of caspofungin susceptible and resistant Candida cells. We showed that both strains are impacted by caspofungin treatment at the nanoscale. Moreover, caspofungin resistant cells exhibited unexpected mechanical behaviour and cell wall composition that were independent of the caspofungin treatment. This work demonstrates how AFM combined to ATR-FTIR can help to identify and to understand cellular properties that are associated with drug resistance, often under evaluated by traditional genetic approaches.

\section{Results and discussion}

A single point mutation in FKS1 gene causes caspofungin resistance. To explore how caspofungin resistance influences cell properties, we used a mutant strain of Candida lusitaniae genetically engineered in vitro for having an increased resistance to caspofungin

(Fig. 1). C. Iusitaniae is an opportunistic pathogenic yeast ${ }^{27}$ belonging to the CTG-clade of 
Candida yeast which decodes the CTG codon as a serine instead of a leucine. This clade contains most of the human pathogenic yeast species. C. Iusitaniae has a haploid genome that is easily amenable to targeted genetic modifications. ${ }^{28}$ The caspofungin resistant strain used here, casp ${ }^{\mathrm{R}}$, was obtained by replacing the FKS1 gene in the WT strain by a FKS1 sequence harbouring a single mutation that results in the substitution of the serine amino acid at position 645 by a proline in the $\beta$-1,3-glucan-synthase. This mutation is located in a "hot spot" gene sequence known to harbour key codons for caspofungin resistance. ${ }^{6,19}$ As a consequence, the resistance was increased by $\sim 250$ fold as the minimal inhibitory concentration (MIC) measured for the wild type (WT) and $\operatorname{casp}^{R}$ strain was $0.125 \mu \mathrm{g} / \mathrm{mL}$ and $32 \mu \mathrm{g} / \mathrm{mL}$, respectively. Hereafter, MIC refers to the minimal inhibitory concentration for the WT strain.

Caspofungin affects the morphology of both susceptible and resistant strains. We used AFM to visualize the surface topography of $C$. lusitaniae WT and casp ${ }^{R}$ cells before and after treatment with caspofungin at $\sim 0.06 \mu \mathrm{g} / \mathrm{mL}$ and $\sim 6.25 \mu \mathrm{g} / \mathrm{mL}$, i.e. 0.5 and 50 times the MIC of WT cells. Without caspofungin treatment, WT and casp ${ }^{R}$ cells appear similar with homogeneous cellular shapes and regular surfaces (Fig. $2 a$ and d). Figure $2 b$ shows WT cells treated with caspofungin at 0.5 MIC. This qualitative analysis reveals that some cells still presented a surface similar to untreated cells while others displayed irregular shapes and surfaces. Imaging of individual cells with altered morphology at higher resolution revealed a bumpy surface (Fig. 2b, lower panel). At 50 MIC of caspofungin, all cells from the WT strain were damaged (Fig. 2c). They presented abnormal shapes with increased sizes suggesting cellular swelling due to caspofungin treatment (mean cell sizes of $3.87 \pm 0.41 \mu \mathrm{m}, 5.08 \pm 0.70$ $\mu \mathrm{m}$ and $6.70 \pm 0.90 \mu \mathrm{m}$ for untreated cells and cells treated with 0.5 and $50 \mathrm{MIC}$, respectively; $n=25$ cells for each condition). The cell surface was irregular with several crests and hollows, 
a feature also observed for mutants of $C$. albicans that present cell wall unmasking. ${ }^{29}$ These results are in good accordance with previous observations achieved by AFM or electron microscopy on other yeast species exposed to caspofungin. ${ }^{9-12}$ For casp ${ }^{R}$ cells, the lowest caspofungin concentration $(0.5 \mathrm{MIC})$ did not induce significant structural changes, suggesting that at this concentration the mutation leading to drug resistance totally preserves the cell from caspofungin effects (Fig. 2e). However, at $50 \mathrm{MIC}$ - which represents a concentration 5 times lower than the MIC of this resistant strain - few cells exhibited abnormal shapes that are were reminiscent of the changes observed for the WT strain (Fig. 2f). Yet, the mean cell size remained constant in all conditions for casp $^{R}$ cells (mean cell sizes of $3.87 \pm 0.40 \mu \mathrm{m}, 3.81 \pm$ $0.50 \mu \mathrm{m}$ and $4.00 \pm 0.40 \mu \mathrm{m}$ for untreated cells and cells treated with 0.5 and $50 \mathrm{MIC}$, respectively; $n=25$ cells for each condition). This observation suggests that resistant strains are also impacted by caspofungin treatment and that the response to the antifungal is heterogeneous.

Caspofungin alters mechanical properties of the cell wall. Based on the morphological differences observed for WT and casp $^{R}$ cells, we decided to investigate the possible mechanical changes induced by the activity of caspofungin towards $\beta$-1,3-D-glucan synthesis in both susceptible and resistant cells. To probe the mechanical properties of the cell wall, AFM tips were used as nanoindentors to record indentation force maps on the surface of isolated yeast cells (Fig. 3a). The shape of the approach force curves directly reflects the mechanical strength of the underneath surface. Force $v s$ indentation depth curves were fitted with the Sneddon model to obtain the corresponding elastic modulus (Fig. 3b, black lines). ${ }^{30,31}$ Without caspofungin treatment, WT and $\operatorname{casp}^{R}$ cells presented comparable elastic properties with elastic moduli ranging from 200 to $3000 \mathrm{kPa}$ (Fig. 3c, f; Fig. 4 and Fig. S1) which is consistent with values measured for other yeast cells. ${ }^{12,32}$ Yet some cells presented higher 
values, especially for casp ${ }^{R}$, documenting a more rigid cell wall that may differ in biochemical composition (see below). After caspofungin treatment at $0.5 \mathrm{MIC}$, the WT elastic modulus did not significantly differ from native conditions although some cells were softer (Fig. 3d; Fig. 4 and Fig. S1). This stability of the elastic modulus suggests that treated cells redirect their cell wall synthesis to preserve their mechanical strength. This observation is in line with studies describing activation of stress responses under caspofungin treatment. ${ }^{16,19,33,34}$ We then investigated how mechanical properties vary when higher caspofungin concentration are used. As shown in Figure 3e, after treatment at 50 MIC, most WT cells were dramatically softer, with elastic modulus $\sim 6$ times lower $(<500 \mathrm{kPa})$, demonstrating that WT cells cannot adapt to the high dose of antifungal (Fig. 3e; Fig. 4 and Fig. S1). Surprisingly, some cells presented a comparable or slightly stiffer cell wall compared to untreated cells (elastic modulus ranging from 1000 to $2500 \mathrm{kPa}$; Fig. 3e, blue bars). This unexpected result revealed that a complex and heterogeneous stress response to caspofungin may exist with some cells capable of modifying their cell wall composition to counteract the weakness resulting from the lack in $\beta-1,3-D-g l u c a n s$ even at high caspofungin concentration (Fig. 4). This heterogeneity in caspofungin effect with some cells unaffected is reminiscent to the microbial persistence observed under antimicrobial treatment. ${ }^{35-37}$

Then, we wanted to decipher whether caspofungin resistance was synonym of stable elastic properties or if caspofungin also induced major mechanical changes in resistant cells. Casp $^{R}$ cells treated with caspofungin at 0.5 MIC presented a stiffer cell wall than untreated cells (Fig. 3g vs. 3f; Fig. 4 and Fig. S1). This stiffening observed for casp ${ }^{R}$ cells clearly attests that $0.5 \mathrm{MIC}$ of caspofungin induces changes in cell wall composition. Caspofungin resistance is associated with a mechanical strengthening also when high drug concentration is used: at 50 MIC of caspofungin, casp ${ }^{R}$ cells stiffening was more pronounced, with elastic modulus 
increasing up to 5000 kPa (Fig. 3h; Fig. 4 and Fig. S1). However, some casp ${ }^{R}$ cells were not able to face caspofungin effect at this high concentration and presented a decreased elastic modulus, a heterogeneity that is consistent with images presented above (Fig. 2f). This nanomechanical analysis reveals that caspofungin effect is not limited to changes in $\beta-1,3-D-$ glucans but includes also other cell wall remodelling that compensates the drug effect through stress pathways. Complementary studies have demonstrated that cell wall stiffening can be attributed to an increased amount of chitin in the cell wall. ${ }^{12,18,29,33}$ Here we show that cell wall stiffening occurs only at low concentration of caspofungin for WT cells, whereas it is also observed at high concentration for resistant strains.

Caspofungin induces major changes in cell wall biochemical composition. As the mechanical cell wall properties are defined by their biochemical composition, we wanted to determine which composition changes were associated with the mechanical features observed under caspofungin treatment. ATR-FTIR was used to establish the biochemical fingerprints of WT and casp ${ }^{R}$ cells treated or not with caspofungin. Figure 5 shows the ATRFTIR spectra obtained for native WT and casp ${ }^{R}$ cells. Slight differences were observed on the normalized spectra of both strains indicating a similar cell wall composition in native conditions. The main differences were observed in the proportions of polysaccharides as the difference spectrum (Fig. 5, purple line) showed bands at 1151 and $1022 \mathrm{~cm}^{-1}$ that may be assigned to $\alpha$-glucans, ${ }^{38}$ present in lower amount in casp ${ }^{\mathrm{R}}$ cell walls.

As expected, treatment of WT cells with caspofungin leads to a decrease in $\beta$-glucans content at $0.5 \mathrm{MIC}$ and $50 \mathrm{MIC}$ (negative bands at 997, 1045 and $1081 \mathrm{~cm}^{-1}$, Fig. 6a) ${ }^{38}$ associated with a decrease of the metabolic activity at 50 MIC (negative bands at 1085 and $1255 \mathrm{~cm}^{-1}$ assigned to nucleic acids ${ }^{39}$, Fig. 6a). We suggest that this reproducible effect is linked to the activity of the antifungal drug that blocks $\beta$-glucan synthesis and may represent secondary 
effect. Interestingly, characteristic bands at 1313, 1378, 1556, 1623 and $1656 \mathrm{~cm}^{-1}$ appeared on the spectra of treated yeasts, revealing that the chitin content increased in the cell wall of treated WT cells at both concentrations of caspofungin and in a dose dependent manner (Fig. 6a). This observation is in line with previous studies showing that low dose of this drug already induces an increase in chitin synthesis to preserve cells from mechanical failures caused by the lack in $\beta$-glucans. ${ }^{9,12,40}$ Moreover, our results at high caspofungin concentration demonstrate that the stress response-associated chitin synthesis in WT cells is activated by the $\beta$-glucans blocking activity of the drug and may represent a mechanism to delay lethal effect. Figure $6 b$ shows the ATR-FTIR spectra of $\operatorname{casp}^{R}$ cells after the treatment at the same two concentrations of caspofungin. The treatment at $0.5 \mathrm{MIC}$ did not induce significant changes in the cell wall of casp ${ }^{R}$ cells as compared with untreated cells (native). This result correlates with the mechanical measurements and the images presented above, and suggests that low concentration of caspofungin does not induce stress responses in resistant cells. Although $\operatorname{casp}^{R}$ cells are resistant to caspofungin treatment at $50 \mathrm{MIC}$, this drug concentration induced changes in their cell wall with a slight decrease in $\beta$-glucans content compensated by a very weak increase in chitin content. Hence, caspofungin resistance in casp ${ }^{R}$ cells is due to the mutation in FKS1 gene that reduces drug-target affinity, combined to the capacity of yeast cells to adapt their cell wall biosynthesis machinery according to external stresses.

\section{Conclusion}

Drug resistance represents an important challenge for the design of new therapeutics and for their appropriate use in health care. Caspofungin is an antifungal drug used since the early 2000's and most resistances are associated with mutations in FKS genes that code for $\beta$ glucan synthases, the drug molecular target. Additionally to the identification of genetic 
markers, understanding the cellular mechanisms underlying drug resistance is a key step towards an improved antifungal therapy. In this study, we used AFM combined to ATR-FTIR to decipher the principal changes induced by caspofungin in WT and isogenic resistant yeast cells. This original approach allowed us to demonstrate that: i) caspofungin treatment alters cell morphology and surface topography; ii) major mechanical changes are observed for both susceptible and resistant strains (Fig. 4); iii) in the presence of caspofungin, increased chitin synthesis is induced to counteract the cell wall stress due to the lack in $\beta$-glucans; iv) FKS mutation leading to caspofungin resistance is also responsible for biochemical cell wall changes, with a slight decrease in $\alpha$ - and $\beta$-glucans associated to chitin increase; v) caspofungin resistance involves an adaptive stress response additionally to the initial loss of action of the drug on the molecular target; and vi) caspofungin effect is heterogeneous suggesting that some cells are unaffected or do not uptake the drug and may constitute persisters. Finally, this work demonstrates that AFM and vibrational spectroscopy are valuable methods to identify cellular mechanisms that are associated with drug resistance.

\section{Methods}

Microorganisms and cultures conditions. C. lusitaniae CBS 6936 (WT) and casp ${ }^{R}$ (bearing the mutation S645P in FKS1) strains were cultivated in YPD medium at $30^{\circ} \mathrm{C}$ with shaking (both strain presented comparable growth in media without caspofungin). The $\operatorname{casp}^{R}$ strain was constructed in the genetic background of the wild type strain CBS 6936 whose complete genome was recently released. ${ }^{41}$ The echinocandin-susceptible FKS1 wild allele of a double auxotrophic trp1, ura3 mutant of 6936 was replaced by two DNA fragments covering the entire FKS1 ORF with its regulatory regions, each of them being fused with one of the wild allele complementing the trp1 and ura3 mutations. ${ }^{28}$ The S645P mutation was introduced in the primers used to amplify the FKS1 DNA fragments by replacing a thymine by a cytosine at 
the nt position 1933 of the gene. After genetic transformation, the yeast clones that had performed replacement of the wild allele by the mutated FKS1 allele were selected on minimal YNB medium. The complete molecular strategy used to introduce mutations in the FKS1 gene of C. Iusitaniae will be published elsewhere. Caspofungin (Merck \& Co., Kenilworth, NJ) was dissolved in sterile demineralised water and maintained at $-80^{\circ} \mathrm{C}$ until use. Minimal inhibitory concentrations (MIC) of caspofungin were determined in 96-well plates as recommended by the Clinical and Laboratory Standards Institute (CLSI) using RPMI medium (1.04\% RPMI1640, 2\% D-glucose, MOPS $0.165 \mathrm{M} \mathrm{pH} 7)$. For drop tests, drops containing 10 to $10^{6}$ colony forming units were deposited on solid RPMI medium containing no caspofungin or supplemented with $16 \mu \mathrm{g} / \mathrm{mL}$ of caspofungin and incubated $48 \mathrm{~h}$ at $30^{\circ} \mathrm{C}$ for growth. For caspofungin treatment, yeast cells were cultivated in RPMI medium to an $\mathrm{OD}_{600 \mathrm{~nm}}=0.02$ and caspofungin was added at 0 (native), $0.06 \mu \mathrm{g} / \mathrm{mL}(0.5 \mathrm{MIC}$ ) or $6 \mu \mathrm{g} / \mathrm{mL}$ (50 MIC). After incubation for $16 \mathrm{~h}$, cells were harvested by centrifugation $\left(3000 \mathrm{~g}, 5 \mathrm{~min}, 20^{\circ} \mathrm{C}\right.$ ), washed thrice in PBS and resuspended in PBS at a final concentration of $1 \times 10^{6}$ cells $\mathrm{mL}^{-1}$.

Atomic force microscopy. AFM experiments were performed at room temperature $\left(20^{\circ} \mathrm{C}\right)$ using a MFP3D-Bio AFM (Asylum Research, Oxford Instruments) and $\mathrm{Si}_{3} \mathrm{~N}_{4}$ cantilevers (MSCT, Microlevers, Bruker corporation). For topography images, cells were deposited for $2 \mathrm{~h}$ on glass surfaces coated with a thin layer of $\mathrm{Cr}(\sim 10 \mathrm{~nm})$ and $A u(\sim 30 \mathrm{~nm})$. Surfaces were gently rinsed in ultrapure water and dried overnight at $30^{\circ} \mathrm{C}$. Measurements of mechanical properties were achieved in PBS on cells trapped in porous membranes (pore size: $3 \mu \mathrm{m}$, Millipore). ${ }^{42}$ The spring constants of the cantilevers were determined using the thermal noise method (nominal spring constant of $0.01 \mathrm{~N} \mathrm{~m}^{-1}$ ). Indentation maps ( $32 \times 32$ force-distance curves) were recorded on areas of $1 \times 1 \mu \mathrm{m}$ on the surface of individual cells with an applied force of $3 \mathrm{nN}$. Yeast cells elastic modulus $(E)$ were obtained by fitting the approach force vs indentation curves 
according to the Sneddon model that refers to the compression of a soft planar interface by a conical tip: $F=\frac{2 E \cdot \operatorname{Tan}(\alpha)}{\pi\left(1-v^{2}\right)} \mathrm{R}^{1 / 2} \delta^{2} \cdot f_{\mathrm{BECC}},{ }^{30,31}$ where $F$ is the loading force, $\delta$ the indentation depth, $E$ the elastic modulus, the $v$ the Poisson coefficient, $\alpha$ the semi-top angle of the tip, and $f_{\mathrm{BECC}}$ is the bottom effect cone correction function. All the curves were analysed by mean of an automatic Matlab algorithm described elsewhere. ${ }^{43}$ Extracted elastic moduli were compiled to obtain the corresponding frequency histograms.

ATR-FTIR spectroscopy. ATR-FTIR spectra were recorded at $20^{\circ} \mathrm{C}$ between 4000 and $800 \mathrm{~cm}^{-1}$ on a Bruker Vertex 70v spectrometer equipped with a $\mathrm{KBr}$ beam splitter and a DTGS detector, and driven by the OPUS 7.5 software. The resolution of the single beam spectra was $4 \mathrm{~cm}^{-1}$. A nine-reflection diamond ATR accessory (DurasamplIR ${ }^{\mathrm{TM}}$, SensIR Technologies, incidence angle: $45^{\circ}$ ) was used for spectra acquisition. The number of bidirectional double-sided interferogram scans was 200, which corresponds to a 2 min accumulation. All interferograms were Fourier processed using the Mertz phase correction mode and a Blackman-Harris three-term apodization function. No ATR correction was performed. One drop of the yeast suspensions in PBS was deposited on the ATR crystal. PBS spectra were used to remove the spectral background. Water vapour subtraction was performed when necessary. The spectra were baseline corrected at 3580, 2750, 1800 and $800 \mathrm{~cm}^{-1}$, and then normalized to 1 in the region $1597-800 \mathrm{~cm}^{-1}$. The chitin spectrum was recorded in the same conditions after deposition of 10 mg of chitin powder (kindly provided by Pr. Bonaly) on the diamond crystal.

Acknowledgements. The authors acknowledge the financial support of ICEEL (Ingenierie, Conception, Energie et Environnement labs) under the reference "KILLMAT" and of the "CNRS, Mission Interdisciplinarité". We thank Merck Sharp \& Dhome Corp. for providing caspofungin and Pr. Bonaly for the chitin. 
Author contributions. FQ, IA, CC, GF, TN and SEKC designed the research, analysed the data and wrote the paper; FQ, IA, CC and SEKC performed the research. 


\section{References}

1. M. A. Pfaller and D. J. Diekema, Clin. Microbiol. Rev., 2007, 20, 133-163.

2. D. W. Denning and W. W. Hope, Trends Microbiol., 2010, 18, 195-204.

3. A. Vermes, H. J. Guchelaar and J. Dankert, J. Antimicrob. Chemother., 2000, 46, 171-179.

4. F. C. Odds, A. J. Brown and N. A. Gow, Trends Microbiol., 2003, 11, 272-279.

5. P. G. Pappas, C. A. Kauffman, D. Andes, D. K. Benjamin, T. F. Calandra, J. E. Edwards, S. G. Filler, J. F. Fisher, B. J. Kullberg, L. Ostrosky-Zeichner, A. C. Reboli, J. H. Rex, T. J. Walsh, J. D. Sobel, Clin. Infect. Dis., 2009, 48, 503-535.

6. D. S. Perlin, Future Microbiol., 2011, 6, 441-457.

7. C. M. Douglas, J. A. D'Ippolito, G. J. Shei, M. Meinz, J. Onishi, J. A. Marrinan, W. Li, G. K. Abruzzo, A. Flattery, K. Bartizal, A. Mitchell and M. B. Kurtz, Antimicrob. Agents Chemother., 1997, 41, 2471-2479.

8. M. B. Kurtz and C. M. Douglas, J. Med. Vet. Mycol., 1997, 35, 79-86.

9. F. C. Bizerra, A. S. Melo, E. Katchburian, E. Freymuller, A. H. Straus, H. K. Takahashi and A. L. Colombo, Antimicrob. Agents Chemother., 2011, 55, 302-310.

10. C. Dunyach, P. Drakulovski, S. Bertout, S. Jouvert, J. Reynes and M. Mallie, Mycoses, 2011, 54, e62-68.

11. S. El-Kirat-Chatel, A. Beaussart, D. Alsteens, D. N. Jackson, P. N. Lipke and Y. F. Dufrêne, Nanoscale, 2013, 5, 1105-1115.

12. C. Formosa, M. Schiavone, H. Martin-Yken, J. M. Francois, R. E. Duval and E. Dague, Antimicrob. Agents Chemother., 2013, 57, 3498-3506.

13. M. C. Arendrup and D. S. Perlin, Curr. Opin. Infect. Dis., 2014, 27, 484-492.

14. C. Reinoso-Martin, C. Schuller, M. Schuetzer-Muehlbauer and K. Kuchler, Eukaryot. Cell, 2003, 2, 1200-1210.

15. S. Markovich, A. Yekutiel, I. Shalit, Y. Shadkchan and N. Osherov, Antimicrob. Agents Chemother., 2004, 48, 3871-3876.

16. L. A. Walker, C. A. Munro, I. de Bruijn, M. D. Lenardon, A. McKinnon and N. A. Gow, PLoS Pathog., 2008, 4, e1000040.

17. C. Gregori, W. Glaser, I. E. Frohner, C. Reinoso-Martin, S. Rupp, C. Schuller and K. Kuchler, Eukaryot Cell., 2011, 10, 1694-1704.

18. K. K. Lee, D. M. Maccallum, M. D. Jacobsen, L. A. Walker, F. C. Odds, N. A. Gow and C. A. Munro, Antimicrob. Agents Chemother., 2012, 56, 208-217.

19. D. S. Perlin, Clin. Infect. Dis., 2015, 61, 612-617.

20. D. Alsteens, A. Beaussart, S. El-Kirat-Chatel, R. M. Sullan and Y. F. Dufrêne, PLoS Pathog., 2013, 9, e1003516.

21. A. Beaussart and S. El-Kirat-Chatel, J. Bionanoscience, 2014, 8, 419-427.

22. Y. F. Dufrêne, MBio, 2014, 5, e01363-01314.

23. G. Francius, O. Domenech, M. P. Mingeot-Leclercq and Y. F. Dufrêne, J. Bacteriol., 2008, 190, 7904-7909.

24. I. Adt, D. Toubas, J. M. Pinon, M. Manfait and G. D. Sockalingum, Arch. Microbiol., 2006, 185, 277-285.

25. M. Cavagna, R. Dell'Anna, F. Monti, F. Rossi and S. Torriani, J. Agric. Food. Chem., 2010, 58, 39-45.

26. A. Galichet, G. D. Sockalingum, A. Belarbi and M. Manfait, FEMS Microbiol. Lett., 2001, 197, 179-186.

27. A. Favel, A. Michel-Nguyen, F. Peyron, C. Martin, L. Thomachot, A. Datry, J. P. Bouchara, S. Challier, T. Noël, C. Chastin and P. Regli, Diagn. Microbiol. Infect. Dis., 2003, 47, 331-339.

28. S. El-Kirat-Chatel, K. Dementhon and T. Noël, Yeast, 2011, 28, 321-330. 
29. S. Hasim, D. P. Allison, S. T. Retterer, A. Hopke, R. T. Wheeler, M. J. Doktycz and T. B. Reynolds, Infect. Immun., 2017, 85, e00601-16.

30. I. N. Sneddon, Int. J. Eng. Sci., 1965, 3, 47-57.

31. N. Gavara and R. S. Chadwick, Nat. Nanotechnol., 2012, 7, 733-736.

32. E. Dague, R. Bitar, H. Ranchon, F. Durand, H. M. Yken and J. M. Francois, Yeast, 2010, 27, 673-684.

33. C. A. Munro, S. Selvaggini, I. de Bruijn, L. Walker, M. D. Lenardon, B. Gerssen, S. Milne, A. J. Brown and N. A. Gow, Mol. Microbiol., 2007, 63, 1399-1413.

34. S. D. Singh, N. Robbins, A. K. Zaas, W. A. Schell, J. R. Perfect and L. E. Cowen, PLoS Pathog., 2009, 5, e1000532.

35. H. T. Taff, K. F. Mitchell, J. A. Edward and D. R. Andes, Future Microbiol., 2013, 8, 1325-1337.

36. D. Lebeaux, V. Leflon-Guibout, J. M. Ghigo and C. Beloin, J. Antimicrob. Chemother., 2015, 70, 1704-1712.

37. A. Harms, E. Maisonneuve and K. Gerdes, Science, 2016, 354, aaf4268.

38. K. G. Sandula Jozef, M. Kacurakova, E. Machova, Carbohydr. Polym., 1999, 8, 247-253.

39. E. Burattini, M. Cavagna, R. Dell'Anna, F. Malvezzi Campeggi, F. Monti, F. Rossi, S. Torriani, Vib. Spectrosc., 2008, 47, 139-147.

40. D. A. Stevens, M. Ichinomiya, Y. Koshi and H. Horiuchi, Antimicrob. Agents Chemother., 2006, 50, 3160-3161.

41. P. Durrens, C. Klopp, N. Biteau, V. Fitton-Ouhabi, K. Dementhon, I. Accoceberry, D. J. Sherman, T. Noël, Genome Announc., 2017, 5, e00724-17.

42. S. Kasas and A. Ikai, Biophys. J., 1995, 68, 1678-1680.

43. P. Polyakov, C. Soussen, J. Duan, J. F. Duval, D. Brie and G. Francius, PLoS One, 2011, 6, e18887. 


\section{Figure legends}

Figure 1. Caspofungin MIC assay. Drop tests showing the growth capacity of wild type (WT, upper lines) and caspofungin resistant (casp ${ }^{R}$, lower lines) strains. Drops containing 10 to $10^{6}$ colony forming units (CFU) were deposited on unsupplemented medium (a) or medium containing $16 \mu \mathrm{g} / \mathrm{mL}$ of caspofungin drug (b).

Figure 2. AFM images in air of caspofungin sensitive and resistant cells. Images were taken in air to enhance the visibility of morphological modifications induced by caspofungin treatment. Large scale deflection (error signal) images of WT $(a, b, c)$ and $\operatorname{casp}^{R}$ cells $(d, e, f)$ without caspofungin treatment $(\mathrm{a}, \mathrm{d})$ and after treatment at $0.5 \mathrm{MIC}(\mathrm{b}, \mathrm{e})$ and $50 \mathrm{MIC}(\mathrm{c}, \mathrm{f})$. Insets are high resolution height images of individual cells showing the surface ultrastructure $(Z$ scale $=500 \mathrm{~nm})$. An enlarged tridimensional view is depicted below each image with the corresponding Z scale (in $\mu \mathrm{m}$ ) on the left.

Figure 3. Mechanical properties of caspofungin sensitive and resistant cells. (a) Principle of AFM mechanical measurement on yeast trapped in a pore. (b) Representative single approach curves (force vs indentation) obtained with and without caspofungin treatment on WT or casp $^{R}$ cells (open blue circles and open red triangles correspond to experimental data of WT and casp ${ }^{R}$ cells, respectively; black lines: theoretical models). (c-h) Elasticity histograms of WT (c-e) and casp ${ }^{R}$ cells (f-h) without caspofungin treatment $(c, f)$ and after treatment ex situ at $0.5 \mathrm{MIC}(\mathrm{d}, \mathrm{g})$ and $50 \mathrm{MIC}(\mathrm{e}, \mathrm{h})$. Each colour corresponds to the data obtained on an individual cell from independent experiments ( $n=1024$ for each cell). Data obtained for 4 additional 
cells for each condition is presented in Fig. S1 and a box-plot summarizing all the data is shown in Fig. 4.

Figure 4. Box-plot summarizing mechanical properties of caspofungin sensitive and resistant cells. Plot showing the distribution of all elastic moduli obtained for 8 cells in each condition ( $n=1024 \times 8$; lines correspond to medians).

Figure 5. ATR-FTIR spectra of native cells. Comparison of the ATR-FTIR normalized spectra obtained without caspofungin treatment for susceptible (WT, black) and resistant (casp ${ }^{R}$, red) C. Iusitaniae cells. The difference spectrum in shown in purple.

Figure 6. ATR-FTIR spectra of caspofungin treated cells. ATR-FTIR normalized spectra of WT (a) and casp ${ }^{R}$ (b) cells without (black) and with caspofungin treatment at 0.5 (red) and 50 (blue) MIC. Spectra in dark blue and purple correspond to the difference spectra of 0.5 and $50 \mathrm{MIC}$ with the spectra of native cells, respectively. For comparison, the spectrum of pure chitin is shown in grey in (a). 


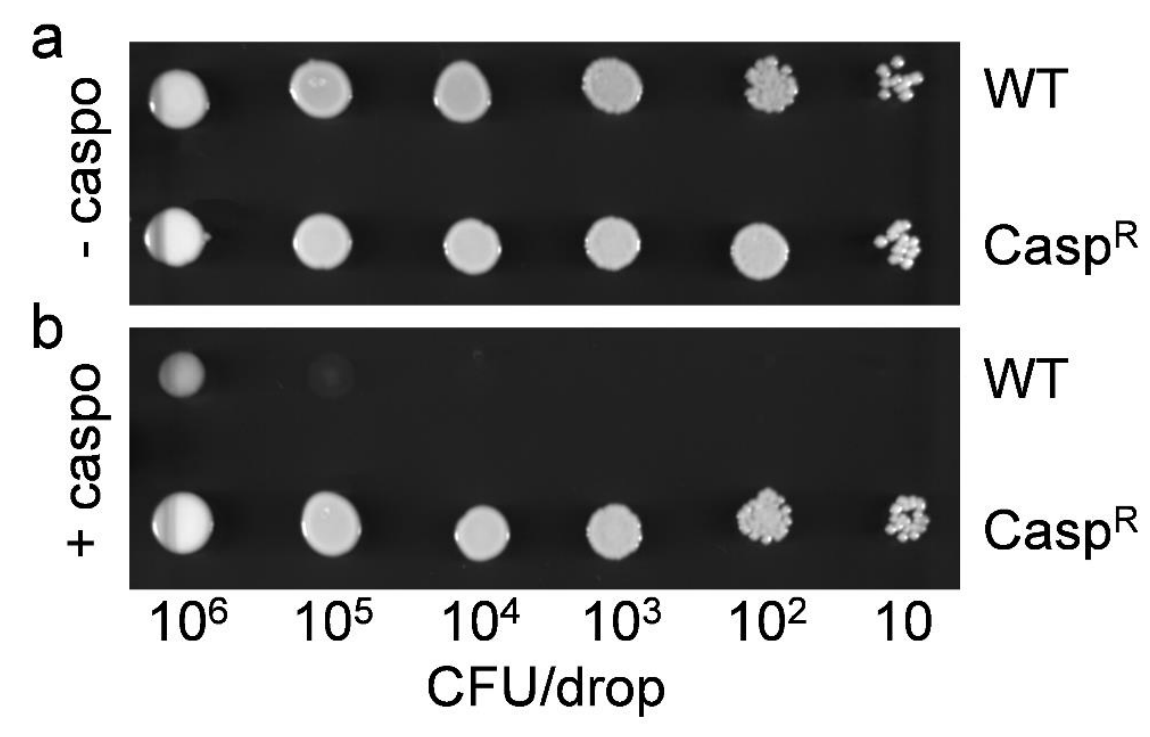

Figure 1 

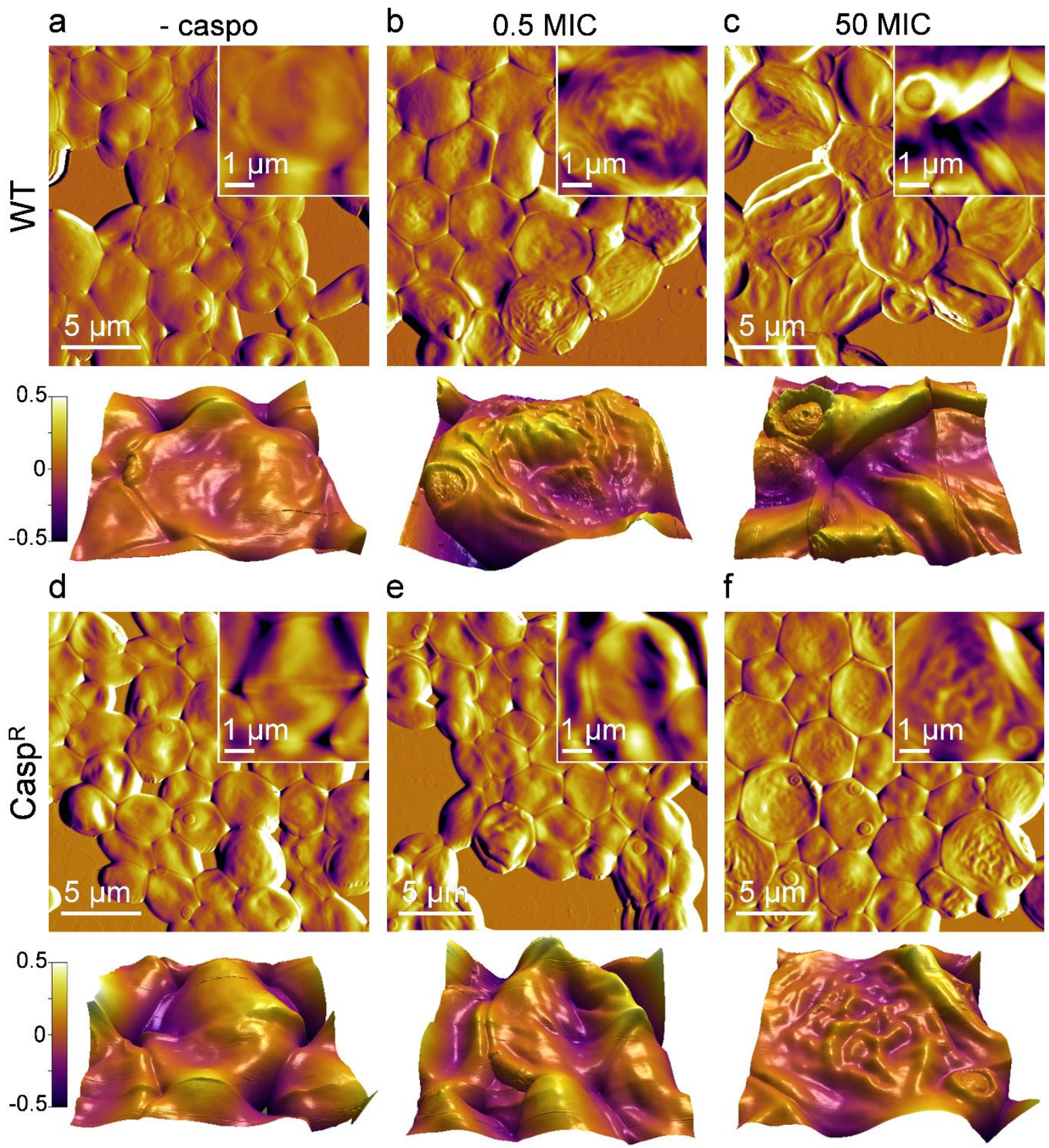

Figure 2 
a
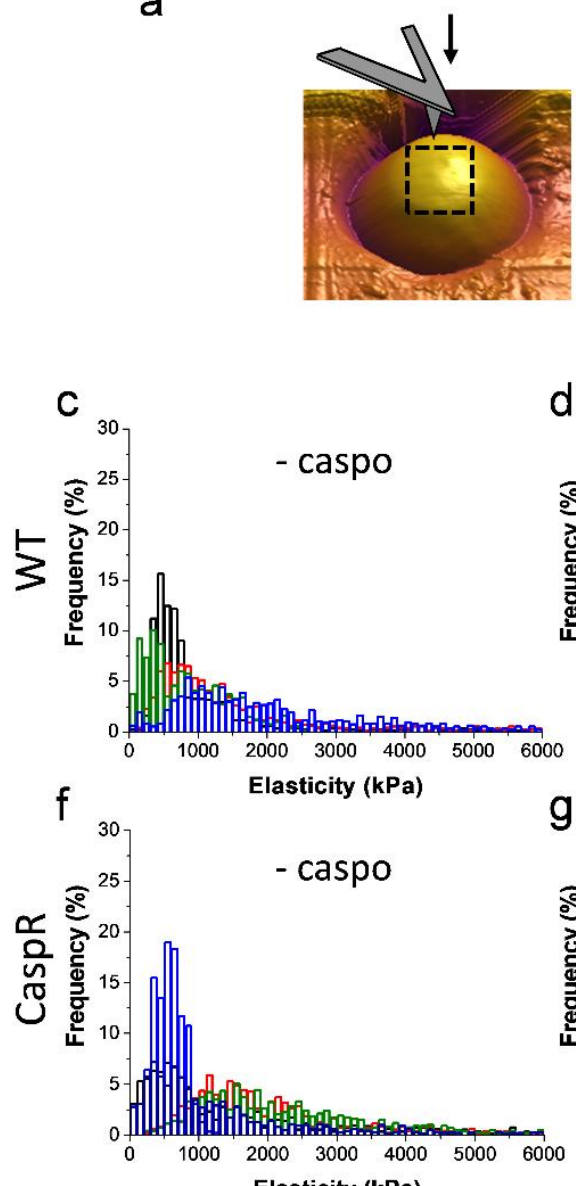

Elasticity (kPa) b

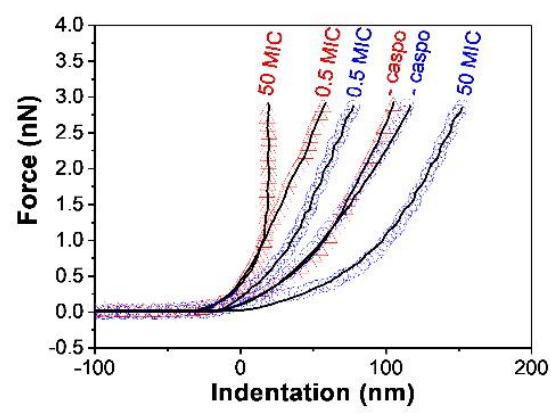

d

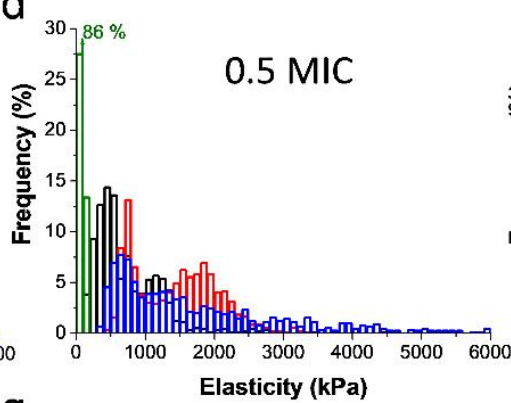

$e_{50}$

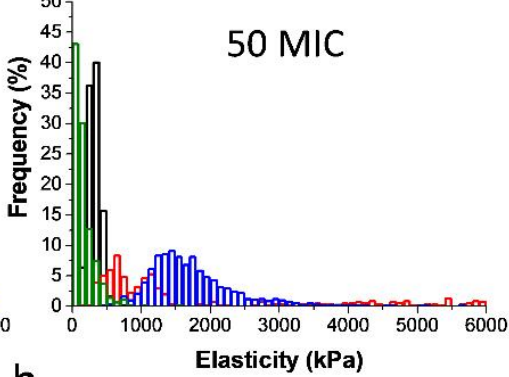

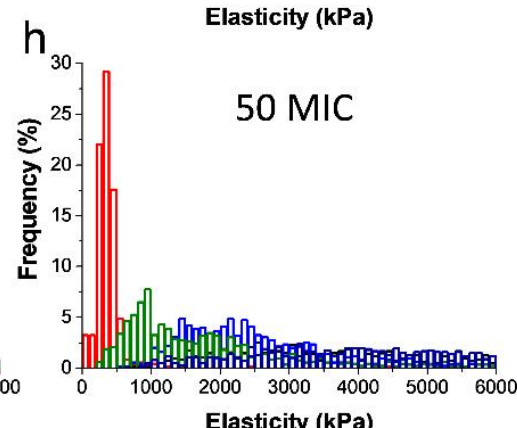

Figure 3 


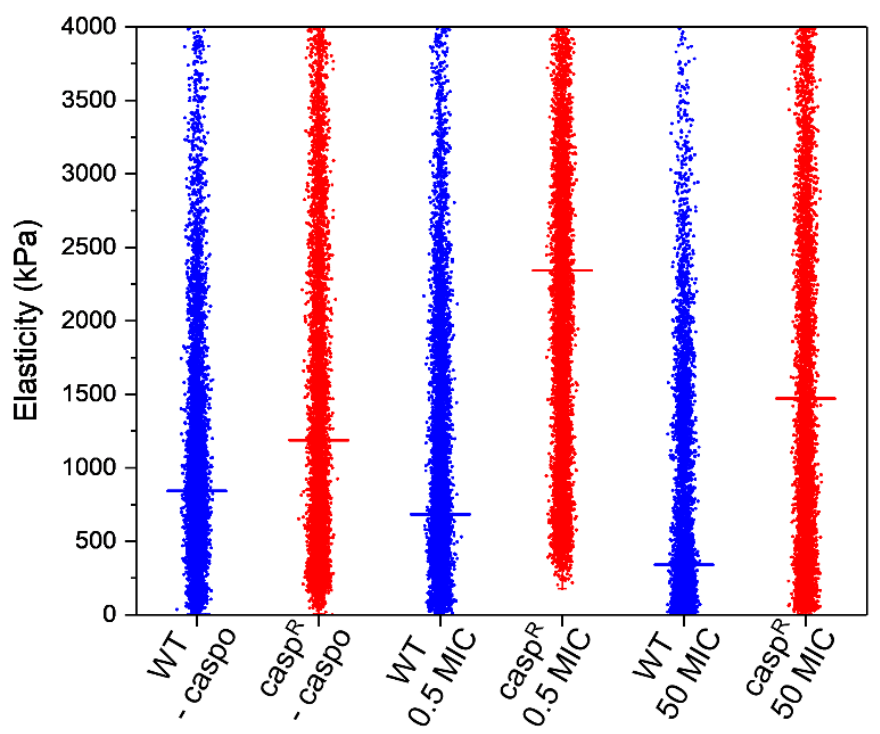

Figure 4 


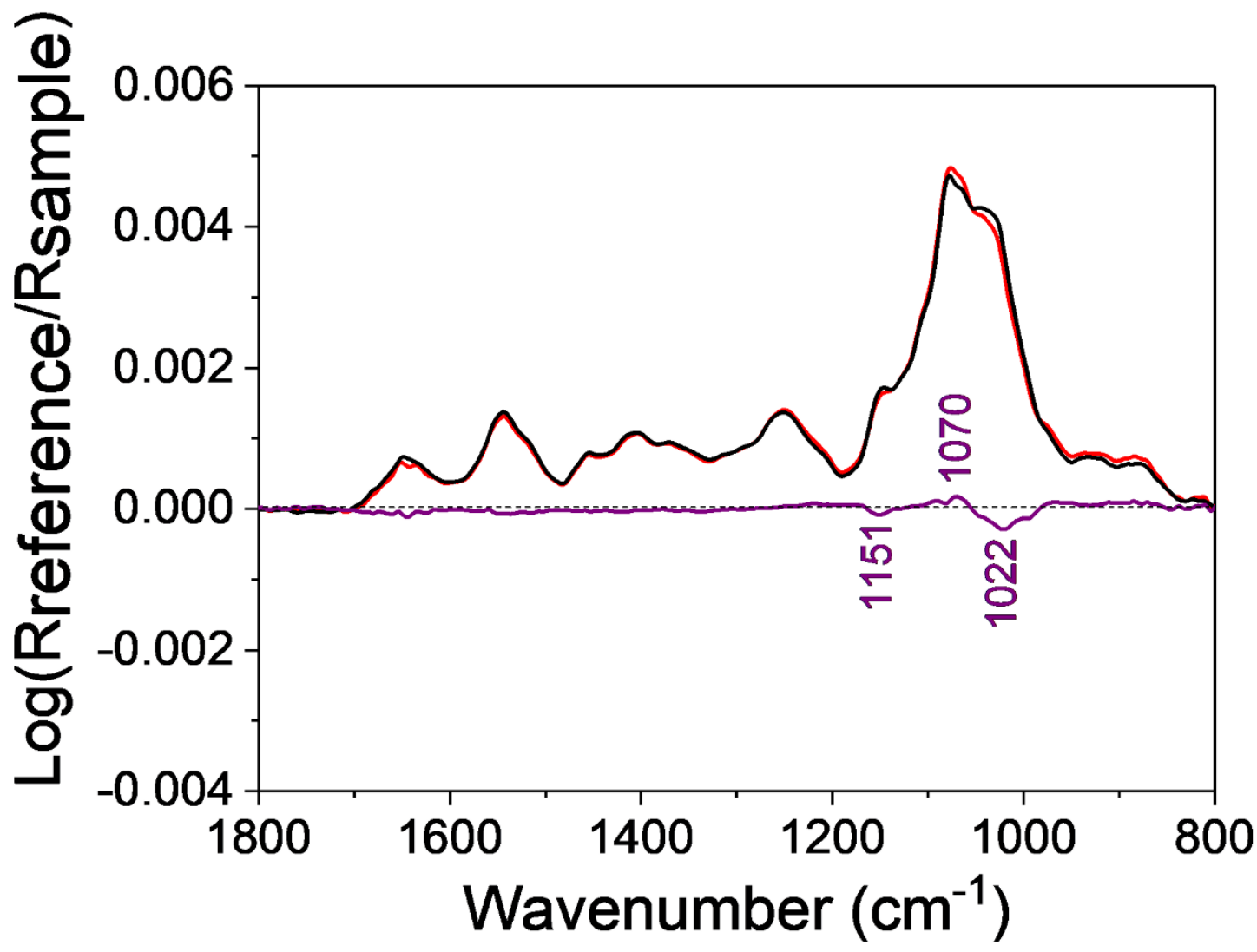

Figure 5 
a

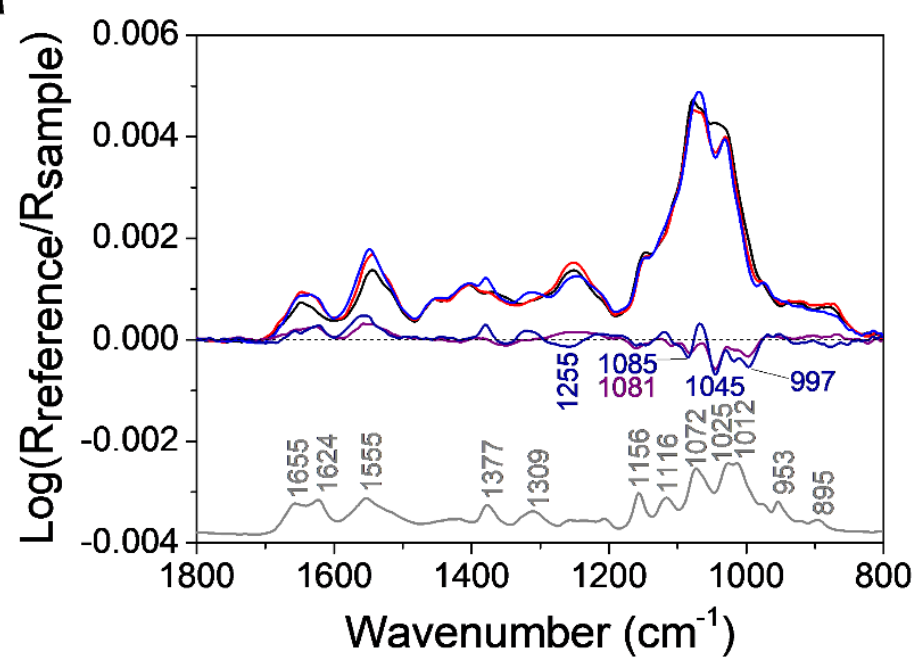

b

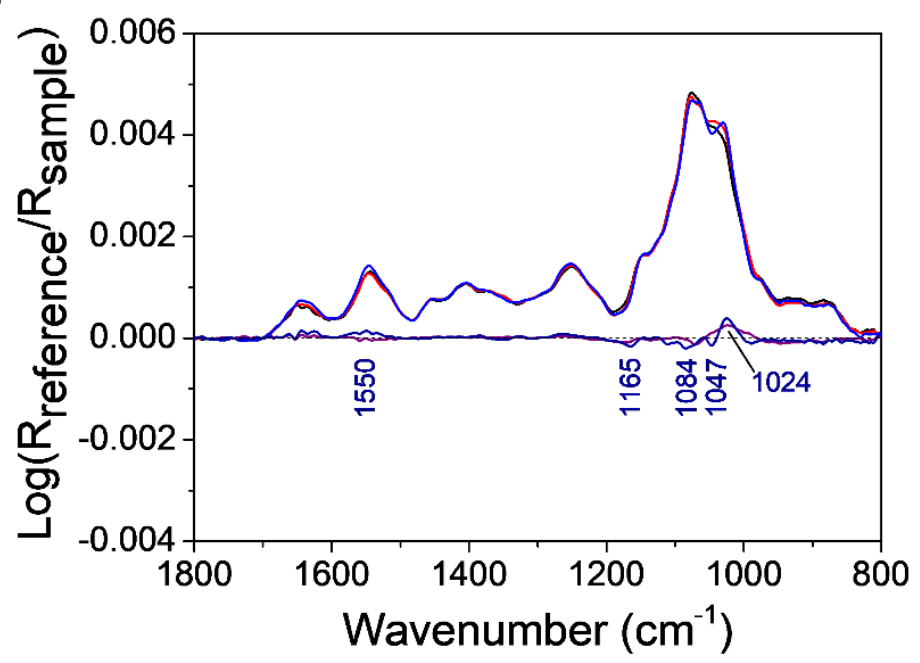

Figure 6 
Supplementary Information for revised manuscript NR-ART-03-2017-002170.R1

\section{AFM combined to ATR-FTIR reveals Candida cell wall changes under}

\section{caspofungin treatment}

Fabienne Quilès, Isabelle Accoceberry, Célia Couzigou, Grégory Francius, Thierry Noël, and Sofiane El-Kirat-Chatel
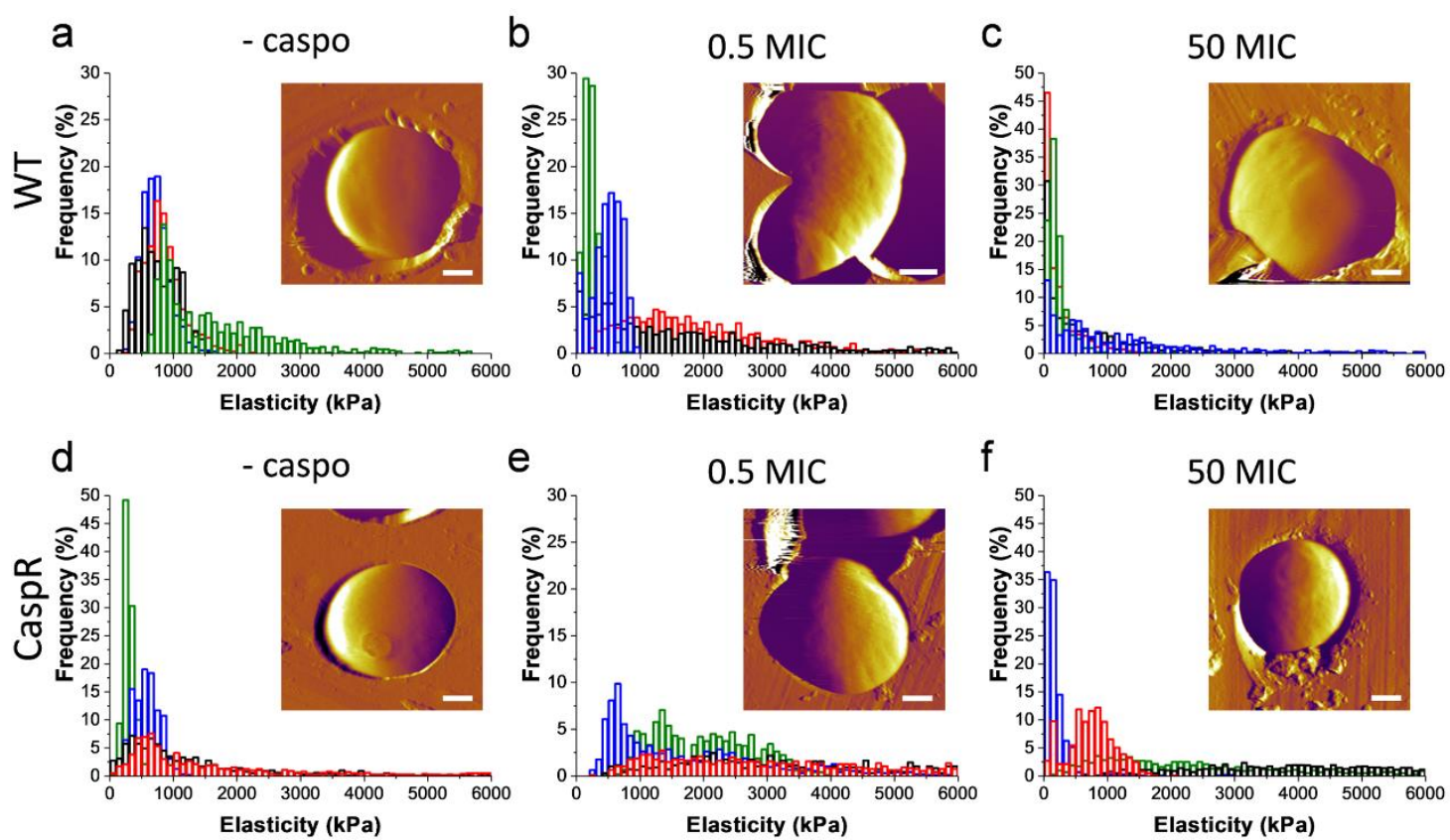

Figure S1. Mechanical properties of caspofungin sensitive and resistant cells. (a-f) Elasticity histograms of WT (a-c) and casp ${ }^{R}$ cells ( $d-f$ ) without caspofungin treatment ( $a$ and $d$ ) and after treatment ex situ at $0.5 \mathrm{MIC}$ ( $\mathrm{b}$ and e) and $50 \mathrm{MIC}$ (c and f). Each colour corresponds to the data obtained on an individual cell from independent experiments ( $n=1024$ for each) (insets are representative AFM deflection images obtained in liquid, scales $=500 \mathrm{~nm}$; morphological changes are less marked than in air). A box-plot summarizing all the data is shown in Fig. S2. 